\title{
VIEWPOINT
}

\section{Should Physical Activity Be Considered Essential During the COVID-19 Pandemic?}

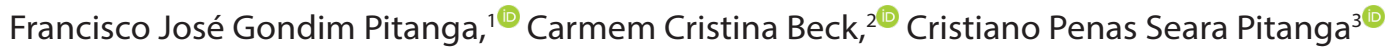 \\ Universidade Federal da Bahia, 'Salvador, BA-Brazil \\ Instituto Federal de Santa Catarina, ${ }^{2}$ Palhoça, SC - Brazil \\ Universidade Católica do Salvador, ${ }^{3}$ Salvador, BA - Brazil
}

\section{Introduction}

The novel coronavirus (COVID-19) disease, considered a pandemic by the World Health Organization (WHO), ${ }^{1}$ which until April 13, 2020, had 1,776,867 confirmed cases with 111,828 deaths worldwide, led the Ministry of Health of Brazil ${ }^{2}$ to prepare a manual with several actions to prevent the spread of the disease. Among these actions, social distancing is recommended, instructing people to remain at home. In addition, many heads of state and municipal executive power across Brazil have issued decrees proposing the closure of several spaces, including gyms, clinics, clubs, and other public and private spaces for physical activity. These actions caused the Brazilian population to have difficulties to continue the practice of physical activity.

On the other hand, since the beginning of the pandemic, some studies have been published in different parts of the world, calling attention to the importance of continuing to practice physical activity. For example, in the city of Wuhan in China, the initial epicenter of the disease, people were recommended to practice physical activity even at home. ${ }^{3}$ In a recent study focused on elderly people, outdoor physical activity and also exercising at home were suggested as therapy to combat the physical and mental consequences of quarantine due to the Covid-19 pandemic. ${ }^{4}$ In addition, according to a recent position of the American College of Sports Medicine, ${ }^{5}$ people should continue to stay physically active while at home during the pandemic.

\section{Keywords}

Pandemics; Coronavirus; COVID-19; Physical Activity; Exercise; Sedentarism; Leisure Activities; Psychological Phenomena.
In line with these publications, legal provisions published in countries such as the United Kingdom ${ }^{6}$ and France ${ }^{7}$ recognized the practice of physical activities in open environments as an essential activity during the quarantine period.

It should also be noted that the literature is consistent in showing the various benefits provided by physical activity for health, especially for the cardiovascular, metabolic ${ }^{8}$ and immune ${ }^{9}$ systems, as well as for mental health. ${ }^{10}$

Therefore, it seems clear that the practice of physical activity both at home and in open environments should be considered as an essential activity during the COVID-19 pandemic in any legal statement issued by government agencies. The objective of this point of view is to describe the evidence for this.

Studies that highlight the importance of staying physically active during the Covid-19 pandemic

The first study was published in the city of Wuhan in China, ${ }^{3}$ the initial epicenter of the disease, where people were recommended to practice physical exercises even at home. The authors recommended that strengthening exercises, balance activities and stretching exercises or a combination of them should be performed. They also recommended walking around the house, lifting and transporting groceries, going up/down stairs, and doing squats, sit-ups and push-ups. In addition, Tai Chi Chuan and Yoga exercises have also been suggested. Physical activity could be done with the aid of technological resources, such as exercise videos and online professional guidance.

Subsequently, a study by researchers from Spain and the USA, ${ }^{4}$ with focus on the elderly, emphasized the importance of outdoor physical activities or exercises

Mailing Address: Francisco José Gondim Pitanga

Universidade Federal da Bahia - Educação Física. Av. Reitor Miguel Calmom, Postal Code 40110-060, Salvador, BA - Brazil

E-mail: pitanga@lognet.com.br 
done at home as therapy to fight against the physical and mental consequences of Covid-19 quarantine. The authors suggested a multicomponent exercise program, including aerobic, resistance, balance, coordination, and mobility training exercises both in outdoor environments and in community homes.

In addition, a recent point of view ${ }^{11}$ suggested the maintenance of physical activity in open environments or indoors during the period of the COVID-19 pandemic. The authors also called attention to the reduction of sedentary behavior, that is, the time we spend sitting, lying down, or reclining, except for the hours of sleep during the day.

\section{Position of the American College of Sports Medicine}

In a recent position of the American College of Sports Medicine ${ }^{5}$ it was suggested the practice of outdoor and indoor physical activities, which could positively modulate the immune function. The outdoor activities, suggested by this entity, were walking or running around the neighborhood, using a local park to be active, taking a bike ride in nature, and also doing gardening and lawn work, and playing active games with the family. The authors recommended that people should always avoid crowded spaces and wash their hands when get home. As indoor physical activities, the American College of Sports Medicine suggested to put on some music and walk quickly around the house, go up down the stairs 2-3 times a day, dance, jump rope, follow an exercise video, and use cardio machines at home.

\section{Legal determinations in European countries during the pandemic}

In recent legal determinations published in countrieslike the United Kingdom and France, the practice of physical activities in open environments was recognizedas an essential activity during the quarantine period. In case of the United Kingdom, ${ }^{6}$ people were instructed to leave home for one of the four reasons: purchases of basic necessities, such as food and medicines, which should be as infrequently as possible; practicing one type of exercise a day, for example, running, walking or cycling (alone or with members of your family); any medical need; to help a vulnerable person; and go to work, but only when it cannot be done at home.

With regard to France, ${ }^{7}$ circulation is allowed upon presentation of a completed, dated and signed form, justifying the reason for leaving. Among the permitted activities, physical activity was considered essential, as explained in the document: short journeys, limited to one hour per day and within a radius of 1 kilometer from home, related either to individual's physical activity (excluding collective sporting practices or involving any proximity to other people), either to a walk with people who live in the same household, or to fill the needs of pets.

Importance of physical activity and its benefits for the cardiovascular, metabolic, and immune systems and mental health

The benefits of physical activity to cardiovascular and metabolic health have been widely and long reported in the literature. Physical activity has an inverse association with blood pressure levels, ${ }^{12}$ diabetes, ${ }^{13}$ lipid changes, ${ }^{14}$ risk of coronary artery disease, ${ }^{15}$ and risk of cardiovascular events, ${ }^{16}$ acting as an important protective factor for different cardiometabolic disorders. In addition, more recently, the importance of reducing sedentary behavior has also been discussed as an important approach to maximize the benefits of physical activity in preventing cardiometabolic disorders. ${ }^{17}$

Regarding the immune system, physical activity, especially at moderate intensity and duration, can favor immune responses and improve resistance of the body. On the other hand, high-intensity and prolonged exercise can cause immunosuppression and therefore should be avoided during the COVID-19 pandemic. $^{9}$

A recent publication ${ }^{18}$ by Italian researchers presents lessons learned from studies on influenza and physical activity in obese patients and suggests that the findings may be considered for COVID-19. The authors emphasize the positive effects on immunomodulation provided by the practice of light- to moderate-intensity physical exercise.$^{18}$ In the same line of reasoning, in a study carried out in the USA, it was observed that physical exercise acts as a preventive agent against viral influenza infection, both in obese and non-obese rats. ${ }^{19}$

As for mental health, several studies have shown that the practice of physical activity can bring important benefits for the prevention of depression, ${ }^{10}$ anxiety, Burnout syndrome and perceived stress. ${ }^{20}$ Thus, physical activity becomes an important ally for the management of these health problems that affect the population, especially during the COVID-19 pandemic. $^{4}$ 


\section{Conclusion}

Considering the benefits of physical activity to the cardiovascular, metabolic, and immune systems, and for mental health, we suggest that any legal determination that may be published by municipal, state or federal agencies consider outdoor physical activities as an essential practice. It must be emphasized that the exercises must be practiced individually or at most with people who live in the same household, avoiding groups or clusters of people together and respecting the safe distance suggested by health entities. Also, especially for elderly people, it is suggested to stay physically active while at home, preferably with online guidance from physical educators. Sedentary behavior should also be reduced, that is, the time we sit, lie down or recline, and time spent in front of the television, computer and the like. Finally, if you feel comfortable and safer, it is suggested to wear masks during walking, running, or cycling.

\section{References}

1. World Health Organization. (WHO). [Internet]. Novel Coronavirus (2019-nCoV); 2020. [citado 13 abr. 2020]. Disponível em: https://www. who.int/.

2. Ministério da Saúde do Brasil [Internet]. O que você precisa saber o Corona Vírus; 2020. [citado 13 abr. 2020]. Disponível em: https:// coronavirus.saude.gov.br/.

3. Chen P, Mao L, Nassis GP, Harmer P, Ainsworth BE, Li F. Coronavirus disease (COVID-19): the need to maintain regular physical activity while taking precautions. J Sport Health Sci. 2020;9(2):103-4.

4. Jiménez-Pavón D, Carbonell-Baeza A, Lavie CJ. Physical exercise as therapy to fight against the mental and physical consequences of COVID-19 quarantine: special focus in older people. Prog Cardiovasc Dis. 2020 Mar 24;pii:S0033-0620(20)30063-3. [Epub ahead of print].

5. American College of Sports Medicine [Internet]. Staying physically active during the COVID-19 pandemic; 2020. [citado 11 abr. 2020]. Disponível em: https://www.acsm.org/.

6. National Health Service/UK [Internet]. Stay at home to stop coronavirus spreading; 2020. [citado 11 abr. 2020]. Disponível em: https://www.nhs.uk/.

7. Consulado-Geral da França no Rio de Janeiro [Internet]. Atestado digital de saída para fins específicos; 2020. [citado 11 abr. 2020]. Disponível em: https://riodejaneiro.consulfrance.org/Comunidade-francesa.

8. Lin X, Alvim SM, Simoes EJ, Bensenor IM, Barreto SM, Schmidt MI, et al. Leisure time physical activity and cardio-metabolic health: results from the Brazilian Longitudinal Study of Adult Health (ELSA-Brasil). J Am Heart Assoc. 2016;5(6):pii003337.

9. Krinski K, Elsangedy HM, Colombo H, Buzzachera CF, Soares IA Campos W, Silva SG. Physical exercise effects in the immunological system. Rev Bras Med. 2010;67(7):227-8.

10. Mammen G, Faulkner G. Physical activity and the prevention of depression: a systematic review of prospective studies. Am J Prev Med. 2013;45(5):649-57.

\section{Author Contributions}

Conception and design of the research: Pitanga FJG. Critical revision of the manuscript for intellectual content: Pitanga FJG, Beck CC, Pitango CPS.

\section{Potential Conflict of Interest}

No potential conflict of interest relevant to this article was reported.

\section{Sources of Funding}

There were no external funding sources for this study.

\section{Study Association}

This study is not associated with any graduation program.

\section{Ethics Approval and Consent to Participate}

This article does not contain any studies with human participants or animals performed by any of the authors.

11. Pitanga FJG, Beck CC, Pitanga CPS. Atividade física e redução do comportamento sedentário durante a pandemia do Coronavírus. Arq Bras Cardiol. 2020. [Epub ahead of print];[online].ahead print. PP.-0-0

12. Pitanga FJ, Lessa I. Relationship between leisure-time physical activity and blood pressure in adults. Arq Bras Cardiol. 2010;95(4):480-4

13. Pitanga FJ, Lessa I, Barbosa PJ, Barbosa SJ, Costa MC, Lopes Ada S Physical activity in the prevention of diabetes in black ethnicity: how much is required? Rev Assoc Med Bras. 2010;56(6):697-704

14. Pitanga FJ. Physical activity and plasmatics lipoproteins in adults male and female. Rev Bras Ciên Mov. 2001;9(4):25-31.

15. Haapanen N, Miilunpalo S, Vuori I, Oja P, Pasanen M. Association of leisure time physical activity with the risk of coronary heart disease, hypertension and diabetes in middle-aged men and women. Int J Epidemiol. 1997;26(4):739-47.

16. Pitanga FJG, Matos SMA, Almeida MDC, Barreto SM, Aquino EML. Leisure-time physical activity, but not commuting physical activity, is associated with cardiovascular risk among ELSA-Brasil participants. Arq Bras Cardiol. 2018;110(1):36-43.

17. Pitanga FJG, Matos SMA, Almeida MDCC, Patrão AL, Molina MDCB, Aquino EM. Association between leisure-time physical activity and sedentary behavior with cardiometabolic health in the ELSA-Brasil participants. SAGE Open Med. 2019;7:1-9.

18. Luzi L, Radaelli MG. Influenza and obesity: its odd relationship and the lessons for COVID-19 pandemic. Acta Diabetol. 2020 Apr 5. [Epub ahead of print].

19. Warren KJ, Olson MM, Thompson NJ, Cahill ML, Wyatt TA, Yoon KJ et al. Exercise improves host response to influenza viral infection in obese and non-obese mice through different mechanisms. PLoS One. 2015;10(6):e0129713.

20. Jonsdottir IH, Rödjer L, Hadzibajramovic E, Börjesson M, Ahlborg G Jr A prospective study of leisure-time physical activity and mental health in Swedish health care workers and social insurance officers. Prev Med. 2010;51(5):373-7. 